\title{
A UTILIZAÇÃO DA DISPENSA DE LICITAÇÃO PARA ATENDER SITUAÇÃO EMERGENCIAL PROVOCADA POR PLANEJAMENTO DEFICIENTE E SUAS CONSEQUENNCIAS
}

\section{USE OF BIDDING SUPPLY TO ATTEND STATE EMERGENCY CAUSED BY POOR PLANNING AND ITS CONSEQUENCES}

\section{${ }^{1}$ Clayton Gomes de Medeiros \\ ${ }^{2}$ Jeison Maikel Kwitschal}

\section{RESUMO}

A interpretação da legislação inerente a licitação no país tem sido matéria de debates jurídicos, principalmente quanto ao instituto da dispensa de licitação, em especial quando justificada na constatação de situação emergencial, o que exige do gestor público providências rápidas e eficazes para debelar ou, ao menos, minorar as consequências lesivas à coletividade. Contudo, o maior dilema está em caracterizar as possibilidades de aplicação do dispositivo legal, já que com o decorrer do tempo se tem vislumbrado a mudança do entendimento jurisprudencial para com a dispensabilidade do certame licitatório quando a emergência é fruto da desídia da Administração Pública.

Palavras-chave: Dispensa de licitação, Situação emergencial, Emergência fabricada, Ausência de planejamento, Improbidade administrativa

\section{ABSTRACT}

The interpretation of the law inherent in bidding in the country has been the subject of legal discussion, especially as the bidding exemption from the institute, particularly when justified in finding emergency situation, which requires the public administrator prompt and effective steps to eradicate or, least minimize the consequences harmful to the community. However, the biggest dilemma is to characterize the application possibilities of the legal provision, since with the passage of time has glimpsed the jurisprudential understanding change towards the dispensability of the bidding event when the emergency is the result of negligence of Public Administration.

Keywords: Bidding waiver, Emergency situation, Manufactured emergency, Planning absence, Administrative dishonesty

\footnotetext{
1 Mestre em Direito pelo Centro Universitário Autônomo do Brasil - UniBrasil, Paraná (Brasil). Professor Universitário do Centro Universitário Autônomo do Brasil - UniBrasil, Paraná (Brasil). E-mail: claytoncgm@hotmail.com

${ }^{2}$ Pós-Graduação em Direito Administrativo e Gestão Pública pela Universidade do Contestado - UnC, Santa Catarina (Brasil). E-mail: jeisonmaikel_adv@hotmail.com
} 


\section{INTRODUÇÃO}

A Lei Federal n. ${ }^{\circ}$ 8.666/93, que rege os contratos e as licitações da Administração Pública, estabelece a necessidade do processo licitatório antes de se contratar com terceiros, contudo, a regra não é absoluta. Uma dessas possibilidades é a decorrente de situação emergencial, que tem lugar quando a situação que a justifica exige da Administração Pública providências rápidas e eficazes para debelar ou, ao menos, minorar as consequências lesivas à coletividade.

Até então, cediço era o entendimento de que sua aplicação se dava apenas nos casos de emergência decorrente de ato ou fato inesperado, sendo a eventualidade deste requisito prático nos julgamentos de casos junto aos Tribunais do país.

Contudo, recentemente, o entendimento tem se alterado, abrindo precedentes importantes para a utilização do instituto para fundamentar a dispensa de certame licitatório quando das situações emergências fictas, entendidas estas como as decorrentes de fatos que embora não esperados, são previsíveis, ante a inércia da administração pública no planejamento de médio e longo prazo.

Assim, oportuno saber se é possível a utilização da dispensa de licitação para atender situação emergencial provocada por planejamento deficiente e suas consequências, para que se aufiram requisitos hábeis para a fundamentação do procedimento administrativo dentro dos órgãos, além de ressaltar a importância de apuração da responsabilidade da desídia levantada na apreciação destes casos.

Toda esta análise, mediante o método dedutivo baseado em bibliografia e decisões dos tribunais de contas, busca-se partir de premissas gerais para as mais específicas, visando confirmar a possibilidade de utilizar o instituto da dispensa de licitação para o atendimento de situação emergencial provocada pela ausência de planejamento dentro da administração pública, já que dentro da Administração Pública, em especial nos municípios, a dificuldade na caracterização do conceito legal de Emergência para fins de aplicação do Art. 24, inciso IV, da Lei Federal n. ${ }^{\circ} 8.666 / 93$ há muito vem tirando o sono de muitos gestores, que na agonia de salvaguardar a continuidade dos serviços públicos de caráter básico, utilizam-se de tal ferramenta para acudir, de forma paliativa, aquilo que só o planejamento poderia prevenir.

Não é difícil encontrar casos em que os gestores municipais, ante uma situação emergencial, criam verdadeiros "teatros" populares para de forma indireta, auferirem a 
possibilidade de dispensarem a necessidade, senão obrigatoriedade, da realização de certames licitatórios, deixando de observar a melhor proposta à Administração,

Embora tal procedimento encurte o trâmite da aquisição de materiais ou da execução de serviços, isso seria facilmente evitado se ao invés de remediar situações eleitoreiras, os entes públicos priorizassem os setores estratégicos, em especial, realizassem o melhoramentos das políticas públicas de médio e longo prazo, com ênfase ao planejamento.

Assim, diante das inúmeras possibilidades de o texto legal possui e da vasta jurisprudência que se tem visto, necessária se faz a caracterização de requisitos para a utilização de tal instituto, principalmente nos casos de emergência ficta.

Devemos enfatizar as consequências da sua utilização, bem como a responsabilização nos casos em que ocorre a descaracterização do escopo da Dispensa de Licitação Emergencial, inclusive apurando-se a responsabilidade administrativa, civil e na esfera da probidade administrativa.

Assim, importante se faz elencar os dispositivos legais já existentes e passíveis de interpretação para viabilizar a fundamentação de pareceres jurídicos nos casos de dispensa de licitação, oriundos de situação emergencial, decorrente da ausência de planejamento da Administração Pública, propondo possibilidades de interpretação da dispensa de licitação em caso de situação emergencial decorrente da desídia dos gestores.

Não obstante, deve-se ante de sua utilização listar os requisitos formais e legais obrigatórios a respaldar o processo físico de dispensa de licitação dentro dos órgãos públicos da Administração Pública, ressaltando sempre a necessidade de apuração de eventuais responsabilidades decorrentes da omissão no planejamento dos gestores públicos.

\section{ELEMENTOS CONSTITUCIONAIS, LEGAIS E JURISPRUDENCIAIS DA DISPENSA DE LICITAÇÃO POR EMERGÊNCIA.}

Assim como qualquer outro mecanismo legislativo de nosso sistema jurídico pátrio, o procedimento ou processo licitatório possui seu fundamento constitucional, e como tal está previsto no art. 37, inciso XXI de nossa Carta Maior, que assim dispõe:

\footnotetext{
“Art. 37. A administração pública direta e indireta de qualquer dos Poderes da União, dos Estados, do Distrito Federal e dos Municípios obedecerá aos princípios de legalidade, impessoalidade, moralidade, publicidade e eficiência e, também, ao seguinte:
} 
(...)

XXI - ressalvados os casos especificados na legislação, as obras, serviços, compras e alienações serão contratados mediante processo de licitação pública que assegure igualdade de condições a todos os concorrentes, com cláusulas que estabeleçam obrigações de pagamento, mantidas as condições efetivas da proposta, nos termos da lei, o qual somente permitirá as exigências de qualificação técnica e econômica indispensáveis à garantia do cumprimento das obrigações."

Em suma, para Alexandre de Moraes (2014, p. 379),

"A Constituição Federal exige a licitação na contratação de obras, serviços, compras e alienações da administração pública direta, indireta e fundacional, de qualquer dos Poderes da União, dos Estados, do Distrito Federal e dos Municípios, pois o princípio da licitação representa exigência superior da própria moralidade administrativa e, como tal, a sua dispensa deverá ocorrer excepcionalmente em casos expressamente especificados em lei, respeitando sempre o interesse público.”

Decorrente de tal preceito coube a União, ante sua competência privativa, estabelecer normas gerais acerca do tema, o que se fez com a promulgação da Lei Federal n. ${ }^{0} 8.666$ de 21 de junho de 1.993, que com algumas alterações, vigora até os dias atuais, trazendo consigo, inúmeros entendimentos e discussões, que ao longo dos anos, vem se aprimorando e tornando a prática administrativa cada vez mais atrelada ao estudo jurídico quando de sua utilização.

A Lei Federal n. ${ }^{\circ} 8.666 / 93$, ora mencionada e que rege os contratos e as licitações da Administração Pública, estabelece, em seu artigo 3..$^{\circ}$ que:

A licitação destina-se a garantir a observância do princípio constitucional da isonomia e a selecionar a proposta mais vantajosa para a Administração e será processada e julgada em estrita conformidade com os princípios básicos da legalidade, da impessoalidade, da moralidade, da igualdade, da publicidade, da probidade administrativa, da vinculação ao instrumento convocatório, do julgamento objetivo e dos que lhe são correlatos.

Para José Afonso da Silva (1992, p. 573),

(...) o princípio da licitação significa que essas contratações ficam sujeitas, com regras, ao procedimento de seleção de propostas mais vantajosas para a administração pública. Constitui um princípio instrumental de realização dos princípios da moralidade administrativa e do tratamento isonômico dos eventuais contratantes com o Poder Público.

Nas palavras de Hely Lopes Meirelles (2002, p. 266), 
A expressão obrigatoriedade de licitação tem um duplo sentido, significando não só a compulsoriedade da licitação em geral como, também, a da modalidade prevista em lei para a espécie, pois atenta contra os princípios de moralidade e eficiência da Administração o uso da modalidade mais singela quando se exige a mais complexas, ou o emprego desta, normalmente mais onerosa quando o objeto do procedimento licitatório não comporta.

Das sábias palavras citadas, possível é confirmar que a escolha do fundamento jurídico para determinada aquisição e consequente escolha da empresa deriva da análise da necessidade administrativa em concreto, para que assim possa o servidor ou gestor público, dentro dos limites legais impostos, "escolher" a modalidade ou procedimento de compra adequado.

Denota-se portanto, que a regra da compulsoriedade das licitações não é absoluta. O Estatuto das Licitações, em alguns casos, dá ao administrador a faculdade de se licitar ou não. Prevê, ainda, casos em que o próprio legislador dispensa ou reconhece a inexigibilidade daquelas. Essas situações, todas em caráter excepcional, estão previstas nos artigos 17, 24 e 25 da Lei ${ }^{\circ} 8.666 / 93$.

Assim, o foco do presente estudo é o artigo 24, o qual trouxe um rol de possibilidades de dispensar a licitação ao administrador, o que embora traga tons de faculdade, confunde-se muitas vezes como uma obrigação, misturando inclusive outros institutos, como a inexigibilidade, tornando ainda mais difícil a aplicação da lei no dia a dia dos órgãos públicos.

Neste sentido, para Maria Sylvia Zanella Di Pietro (2014, p. 395),

A diferença básica entre as duas hipóteses está no fato de que, na dispensa, há possibilidade de competição que justifique a licitação; de modo que a lei faculta a dispensa, que fica inserida na competência discricionária da Administração. Nos casos de Inexigibilidade, não há esta possibilidade de competição, porque só existe um objeto ou uma pessoa que atenda às necessidades da Administração; a licitação é, portanto, inviável.

Contudo, este não é o caso da previsão legal contida no inciso IV, do art. 24, da Lei Federal n. ${ }^{\circ} 8.666 / 93$, que possui requisitos extrínsecos e intrínsecos diferentes da maioria dos casos legalmente previstos para dispensar um certame licitatório, isto porque tal hipótese é tida como de "categoria excepcional", ou seja (DI PIETRO, 2014, p. 398), 
(...) quando a demora do procedimento é incompatível com a urgência na celebração do contrato ou quando sua realização puder, ao invés de favorecer, vir a contrariar o interesse público, ou ainda quando houver comprovado desinteresse dos particulares no objeto do contrato.

\section{A UTILIZAÇÃO DO INSTITUO DA DISPENSA DE LICITAÇÃO EM SITUAÇÃO DE EMERGÊNCIA FABRICADA.}

Sendo assim, excepcional é o instituto da Dispensa de Licitação por Emergência podendo-se afirmar que este chega a ser o que mais gera questionamentos perante os diversos Tribunais, na forma prevista no art. 24, inciso IV, da Lei Geral de Licitações:

\footnotetext{
Art. 24. (...) IV - nos casos de emergência ou de calamidade pública, quando caracterizada urgência de atendimento de situação que possa ocasionar prejuízo ou comprometer a segurança de pessoas, obras, serviços, equipamentos e outros bens, públicos ou particulares, e somente para os bens necessários ao atendimento da situação emergencial ou calamitosa, e para as parcelas de obras e serviços que possam ser concluídas no prazo máximo de 180 (cento e oitenta) dias consecutivos e ininterruptos, contados da ocorrência da emergência ou calamidade, vedada a prorrogação dos respectivos contratos.
}

Embora o dispositivo legal traga duas hipóteses de aplicação - emergência e calamidade pública - limitaremos o estudo a primeira hipótese, já que a diferenciação das duas situações também possui divergência doutrinária e jurisprudencial, mas sob o enfoque legal do Decreto Federal n. ${ }^{\circ} 7.257 / 10$, pode-se afirmar que:

\footnotetext{
Art. $2^{\circ} .(\ldots)$

III - situação de emergência: situação anormal, provocada por desastres, causando danos e prejuízos que impliquem o comprometimento parcial da capacidade de resposta do poder público do ente atingido;

IV - estado de calamidade pública: situação anormal, provocada por desastres, causando danos e prejuízos que impliquem o comprometimento substancial da capacidade de resposta do poder público do ente atingido;
}

Vencida esta diferenciação, ressalta-se que a dificuldade de se encontrar um parâmetro hábil de aplicação do instituto da dispensa nos casos de emergência é mera 
consequência da impossibilidade jurídica de se conceituar o que é realmente emergencial, ou em outras palavras, se a emergência é suficiente para dispensar o procedimento licitatório.

Para tanto, devemos utilizar o texto normativo existente e complementar ao artigo 24, já que em sequência, o art. 26, em seu parágrafo único, inciso I, aduz que o processo de dispensa será instruído com a caracterização da situação emergencial ou calamitosa que justifique a dispensa, quando for o caso, ou seja, podemos abstrair três requisitos para a caracterização do caso de dispensabilidade: (i) a caracterização da situação de emergência ou calamidade pública, (ii) a urgência no atendimento da situação e (iii) o risco de prejuízo à comunidade.

Segundo Marçal Justen Filho, (2012, p. 249)

\begin{abstract}
A emergência consiste em ocorrência fática que produz modificação na situação visualizada pelo legislador como padrão [...] No caso específico das contratações diretas, emergência significa necessidade de atendimento imediato a certos interesses. Demora em realizar a prestação produziria risco de sacrifício de valores tutelados pelo ordenamento jurídico. Como a licitação pressupõe certa demora para seu trâmite, submeter a contratação ao processo licitatório propiciaria a concretização do sacrifício a esses valores.
\end{abstract}

Portanto, o sentido da palavra emergência deve estar relacionado diretamente com o tempo necessário à realização da licitação, ou seja, o inciso IV do artigo 24 pressupõe, ainda, a urgência no atendimento das situações em questão.

Essa urgência, segundo o Tribunal de Contas da União (Decisão n. ${ }^{\circ}$ 347/1994), "(...) deve ser qualificada pelo risco da ocorrência de prejuízo ou comprometimento da segurança de pessoas, obras, serviços, equipamentos e outros bens (...)".

Desta feita, compreensível porquê o Tribunal de Contas da União tem servido de parâmetro para inúmeros estudos acerca do presente tema, assim como no magnífico estudo produzido por Luciani Coimbra de Carvalho e Leonardo Chaves de Carvalho, (2014, p. 7-34) que auferiram dentro dos acórdãos do referido Tribunal as seguintes constatações:

\footnotetext{
Após o levantamento e análise dos acórdãos, verificou-se que em 9 (nove) deles havia contratos de dispensa por emergência que foram considerados regulares, sendo que, além desses, havia também um contrato classificado como regular, porém com ressalvas, uma vez que as justificativas dos administradores públicos foram aceitas por serem consideradas capazes de elidir indícios de irregularidades com fundamento no princípio da insignificância (Acórdãos: 2190/2011 - Plenário; 4788/2011 - Segunda Câmara; 1138/2011 - Plenário; 106/2011 - Plenário;
} 
3238/2010 - Plenário; 5903-2010 - Segunda Câmara; 3745/2010 - Primeira Câmara; 1901/2009 - Plenário; 977/2009 - Plenário e 454/2009 - Plenário). Havia 4 (quatro) contratos considerados irregulares; contudo, foram aceitas as justificativas apresentadas pelos responsáveis aos ministros do TCU. Na análise das justificativas, os ministros consideraram: a) a necessidade da contratação e o prejuízo à sociedade que o atraso na contratação causaria (acórdão n. 640/2011 - Plenário; 8456/2010 Primeira Câmara; acórdão 435/2010 - Primeira Câmara e acórdão 713/2009Plenário); b) ausência de comprovação de má-fé do gestor (acórdão n. 640/2011 Plenário; acórdão 435/2010 - Primeira Câmara e acórdão 713/2009-Plenário); c) a presença de fatos alheios à vontade dos responsáveis que interferiram significativamente na tomada de decisões (acórdão n. 640/2011 - Plenário; acórdão 8456/2010 - Primeira Câmara e acórdão 713/2009-Plenário); d) ausência de prejuízo ao erário: acórdão 435/2010 - Primeira Câmara; e e) vedação ao enriquecimento ilícito e pagamento a terceiros de boa-fé (acórdão 713/2009-Plenário). Antes de adentrar nas razões das irregularidades, necessário constar e esclarecer que, em vários destes contratos analisados, havia mais de um motivo que, conjuntamente, levava a contratação direta emergencial ser considerada irregular. A irregularidade mais encontrada foi a falta de planejamento.

Inúmeras foram as conclusões obtidas com o presente estudo, assim como igualmente expõem os autores:

Em 34 (trinta e quatro) acórdãos foi apontado que a emergência simplesmente decorreu da desordem administrativa, uma vez que, na maioria dos casos, não houve planejamento com objetivos definidos, a fim de encontrar soluções prévias e eficientes, para que não se chegasse ao ponto de caracterizar uma situação como emergencial. Em 14 (quatorze) acórdãos foi mencionado que a situação de emergência se deu por desídia, apontada a inércia do administrador público, o qual deixou de agir e planejar no momento correto para que a emergência não se configurasse. A má gestão administrativa dos recursos disponíveis fez com que a contratação emergencial fosse considerada irregular em 3 (três) acórdãos. A falta de justificativa foi a tese adotada pelo ministro relator para decretar irregular a contratação sem licitação devido à emergência em outros 3 (três) acórdãos. Houve 6 (seis) acórdãos procurando demonstrar que a irregularidade se concentrava na emergência ficta ou fabricada, ou seja, aquela emergência que o administrador público deu causa por conta de sua inércia, desídia ou falta de planejamento. Como exemplos encontrados na pesquisa estão: inauguração de instalações públicas com a presença de governador de estado; contratação de escritório de advocacia; atraso em obras; calamidade decretada erroneamente e caos na saúde pública. Por fim, em 2 (dois) acórdãos os contratos feitos com base na emergência foram classificados 
como irregulares pelos ministros do TCU porque a dispensa da licitação foi justificada por uma situação genérica, ou seja, não houve demonstração de que a contratação direta seria o meio efetivo e mais adequado para eliminar o risco de dano. As justificativas se basearam no combate à seca e na necessidade de preservação da segurança pública pela construção de um presídio, situações amplas e, de certa forma, previsíveis e habituais aos administradores públicos; portanto, o contrato emergencial sem licitação não seria a solução para estes problemas. Verificou-se que há utilização de uma decisão-paradigma (Decisão 347/1994) com os pressupostos autorizadores dos contratos emergenciais.

Assim, concluem que:

São quatro os pressupostos analisados: a) que a situação adversa, dada como de emergência ou de calamidade pública, não tenha se originado, total ou parcialmente, da falta de planejamento, da desídia administrativa ou da má gestão dos recursos disponíveis; b) que exista urgência concreta e efetiva do atendimento à situação decorrente do estado emergencial ou calamitoso, visando afastar risco de danos a bens ou à saúde ou à vida de pessoas; c) que o risco, além de concreto e efetivamente provável, se mostre iminente e especialmente gravoso e d) que a imediata efetivação, por meio de contratação com terceiro, de determinadas obras, serviços ou compras, segundo as especificações e quantitativos tecnicamente apurados, seja o meio adequado, efetivo e eficiente de afastar o risco iminente detectado. Também se levantou que o TCU admite a contratação emergencial em alguns casos ainda que comprovada a falta de planejamento administrativo ou de previsibilidade da emergência. Tal posicionamento tem como precedente o Acórdão 1876/2007.

Ao fim do estudo, os autores concluem que "posição adotada é no sentido de verificar a imprevisibilidade da necessidade (...), recorrendo ao princípio da eficiência (...), para a análise da situação emergencial," o que deveras, é cabível e primordial quando da utilização do instituto da dispensa nos casos de emergência ficta.

Isso tudo, sempre utilizando como base jurídica o princípio da eficiência, que sobressai para com outros princípios de caráter infraconstitucional. Segundo CARVALHO (2009, p. 268), o princípio serve de fator de agregação para outras normas do ordenamento jurídico. Realizando-se um corte metodológico dos princípios constitucionais, isolando-se também os princípios que regem a Administração Pública, pode-se afirmar que o princípio da eficiência conduz todo o seu atuar.

Tal premissa, além de possuir força constitucional, denota a preocupação na solução mais hábil e rápida para a emergência existente, e nesse sentido Jorge Ulisses Jacoby 
Fernandes (2004, p. 178-9) entende que "se ficar caracterizada a emergência e todos os outros requisitos estabelecidos nesse dispositivo, pouco importa se a mesma decorra da inércia do agente da Administração".

Para ele, a sociedade não pode ser "duplamente penalizada pela incompetência dos servidores públicos ou agentes políticos”. Assim também entende Lucas Rocha Furtado (2009, p. 77-8), ao "admitir que a inércia do administrador possa criar situação emergencial que venha a legitimar a contratação direta significa, na prática, abrir as portas para todo o tipo de desmando em matéria de licitação.”

Nesse mesmo sentido, tem-se a Decisão n. ${ }^{\circ} 3.472 / 2002$ do Tribunal de Contas do Estado de Santa Catarina, na qual entendeu-se que "a dispensa de licitação embasada no art. 24, IV , da Lei Federal n. ${ }^{o}$ 8.666/93 só é cabível em situação de emergência ou calamidade, devidamente comprovada, que ponha em risco a segurança das pessoas."

Assim são as palavras de Maria Sylvia Zanella Di Pietro (1998, p. 91)

\footnotetext{
O enfoque, portanto, delimitador da definição de emergência e urgência, parece convergir ao aspecto "tempo", ou seja, à verificação de que a via normal de decurso de um procedimento licitatório, sem que medidas efetivas sejam imediatamente adotadas pelo administrador, pode transformar-se em resultado danoso às coisas e pessoas, comprometendo a segurança das mesmas.
}

Denota-se que por inúmeras vezes nos deparamos com justificativa de gestão embasando a dispensa do devido procedimento licitatório. Não em raros casos a Administração Pública, diante da ausência de planejamento ou, em sendo este ineficaz, busca a usual justificativa de ver atendida determinada situação como se esta o fosse imprevisível e portanto, passível de dispensa emergencial.

Contudo, o que se vislumbra é uma desídia injustificada do administrador que não elencou em tempo hábil suas necessidades ou prioridades, incorrendo na definição doutrinária de "emergência fabricada", vindo esta a subsidiar a ação/omissão, dolosa ou culposa do administrador, decorrente da falta de planejamento, da desídia administrativa ou da má gestão dos recursos públicos.

Diante de tal situação, os Tribunais até pouco tempo atrás, vinham entendendo que não seria possível fundamentar a emergência ante a "fabricação" desta pelo próprio administrador, punindo portando, aquele que fizesse utilizar da permissiva legal do art. 24, IV da Lei de Licitações para suprir as necessidades decorrentes da emergência ficta elencada, assim como ocorreu nos Processos LCC 09/00077000 e REC 08/00339460, que tramitaram no Colendo Tribunal de Contas Catarinense. 
Em outras palavras, comum era a Administração Pública não prever a contratação de determinado serviço, ou aquisição de bens, vindo a dispensar a licitação por não haver tempo hábil para atender a demanda não prevista, embora sabida.

A emergência fabricada exige desídia do administrador. Aliás, como alerta Marçal Justen Filho (2012, p. 341), "havendo risco de lesão a interesses, a contratação deve ser realizada, punindo-se o agente que não adotou as cautelas necessárias”. Esclarece que a emergência fabricada acontece quando "a Administração deixa de tomar tempestivamente as providencias necessárias à realização da licitação previsível".

Isto, evidentemente, pode até ter ocorrido, mas não sob o comando e a responsabilidade do administrador, que pode ter assumido sua gestão com o problema à "beira de explodir," não tendo alternativa, senão dispensar a licitação.

Desta feita, com o advento do Acórdão n. ${ }^{\circ}$ 1.876/2007, do Plenário do TCU, iniciouse um processo de modificação desse entendimento:

\begin{abstract}
A situação prevista no art. $24, \mathrm{IV}$, da Lei n. ${ }^{\circ} 8.666 / 93$ não distingue a emergência real, resultante do imprevisível, daquela resultante da incúria ou inércia administrativa, sendo cabível, em ambas as hipóteses, a contratação direta, desde que devidamente caracterizada a urgência de atendimento a situação que possa ocasionar prejuízo ou comprometer a segurança de pessoas, obras, serviços, equipamentos e outros bens, públicos ou particulares.
\end{abstract}

Ainda, entendeu o TCU (Decisão n. ${ }^{\circ}$ 138/98) que,

\begin{abstract}
Estará incorrendo em duplo erro o administrador que, ante a situação de iminente perigo, deixar de adotar as situações emergenciais recomendáveis, ainda que a emergência tenha sido causada por incúria administrativa. Há que se fazer a clara definição da responsabilidade: na eventual situação aludida, o responsável responderá pela incúria, não pela contratação emergencial.
\end{abstract}

Aliás, inadmissível seria a inércia da Administração Pública diante da situação fática de emergência instaurada, independentemente da falta de planejamento administrativo. Assim, para que se visualize a necessidade da contratação direta, mediante Dispensa de Licitação, a doutrina coloca dois pressupostos como obrigatórios para a formalização desta modalidade de contratação, sendo estes: a demonstração cabal e efetiva da potencialidade do dano e a demonstração de que a contratação é via adequada e efetiva para eliminar o risco. 
Assim aduz JUSTEN FILHO (2005, p. 239),

Em última análise, aplica-se o princípio da proporcionalidade. A contratação deverá ser o instrumento satisfatório de eliminação do risco de sacrifício dos interesses envolvidos. Mas não haverá cabimento em promover contratações que ultrapassem a dimensão e os limites da preservação e realização dos valores em risco.

A contratação direta nos casos de emergência tem lugar quando a situação que a justifica demanda da Administração Pública providências urgentes a fim de evitar prejuízos ou repelir os riscos de danos às pessoas, bens ou serviços, públicos ou privados, assim como ocorreu no caso analisado no Prejulgado n. ${ }^{\circ} 1395$ do Tribunal de Contas do Estado de Santa Catarina que possibilitou excepcionalmente ao administrador, desde que de forma justificada e comprovada, dispensasse a licitação.

Prejulgado 1395.

O planejamento inadequado em relação a crescimento de demanda de consumidores de energia elétrica exclui a caracterização de emergência e possibilidade de dispensa de licitação para efetivação de obra de linha de transmissão e subestação.

Excepcionalmente, se o administrador justificar e comprovar que os prejuízos aos consumidores de energia elétrica serão maiores sem a efetivação da obra de linha de transmissão e subestação, aliando aos custos projeção de valores que poderá ter de dispender, em virtude de indenizações decorrentes de processos judiciais e multas administrativas, poderá dispensar a licitação com fulcro no art. 24, IV, da Lei Federal n. ${ }^{\circ} 8.666 / 93$, desde que a execução da obra seja concluída em 180 dias.

Ademais, dentro das limitações impostas por lei, a dispensa de licitação por emergência somente deverá acontecer quando cabalmente demonstrado a potencialidade do dano que se pretende repelir, bem como a clara indicação de que este constitui meio único adequado e suficiente para eliminação dos riscos, conforme preceitua o Tribunal de Contas da União (Acórdão 1.920/2011):

$\mathrm{Na}$ formalização dos processos de dispensa de licitação, observe com rigor os preceitos da Lei n. ${ }^{\circ} 8.666 / 1993$, em especial as hipóteses em que a licitação é dispensável (art. 24), a obrigatoriedade nas obras e serviços da existência de orçamento detalhado em planilhas que expressem a composição de todos os seus custos unitários (art. $7^{\circ}, \S 2^{\circ}$, inc. II, c/c art. $7^{\circ}, \S 9^{\circ}$ ), a vedação da indicação de marcas (art. $7^{\circ}, \S 5^{\circ}, \mathrm{c} / \mathrm{c}$ art. $7^{\circ}, \S 9^{\circ}$ ), os critérios de publicidade (arts. 16 e 26, “caput”), os casos em que é obrigatório o instrumento contratual (art. 62, "caput”), bem como os elementos que a instruirão relacionados no parágrafo único do art. 26. 
Conforme já mencionado, delinear requisitos e formas de justificar a contratação para atender uma emergência decorrente de desídia ou outro motivo administrativo, dispensando o devido certame licitatório é matéria que há muito intriga os operadores do direito, inclusive antes da promulgação da Lei Federal n. ${ }^{\circ}$ 8.666/93.

Jorge Hélio Chaves de Oliveira (1993, p. 107-111) teve um artigo publicado no ano de 1.993, e embora já sob a égide a Lei Geral de Licitações, ainda que de forma precária, buscou em época anterior a vigência desta, traçar fundamentos ou a inexistência para dispensar o certame de disputa concorrencial para atender uma demanda então provocada pelo gestor. Assim vejamos:

Se a regra constitucional é licitar, no que tange aos negócios firmados por entidades geridas ou controladas pelo Poder Público, já, entretanto, as hipóteses previstas no Decreto-Lei n. ${ }^{\circ}$ 2.300/86, em que o procedimento licitatório é dispensado (art. 15, I e II), dispensável (art. 22, I a XI) ou, simplesmente, inexigido (art. 23, I a V) e até vedado (art. 23, $\S 1^{\circ}$ ).

Poder-se-ia, então, afirmar que a regra corre imenso e constante risco de ser devorada pela prática, na qual um administrador, guardadas suas competências, dispondo de "hábil" assessoria jurídica, driblaria a norma principiológica da licitação muito mais vezes do que recorreria a ela. Pura precipitação. A postos, os tribunais e Conselhos de contas, na correta observância do que lhes é conferido por lei, caminham - ou devem caminhar - céleres na contra mão daqueles que buscam burlar o legado legal.

Neste breve estudo procuramos priorizar a preocupação com uma situação que nos parece ser a mais arrimada, dentre as polêmicas que a realidade políticoadministrativa brasileira nos oferece, pelos administradores mais "apressados" em prover ao bem-estar social: os casos de emergenciais e urgentes como requisito para a dispensa de competente licitação e consequente contratação direta com particular, não sem antes cumprir a formalidade - às vezes, nem isso - de apresentar à autoridade competente, no mínimo, três propostas de possíveis fornecedores do objeto desejado, dentre as quais se escolherá - em regra, segundo o fator menor preço - o prestador do serviço ou vendedor do bem desejado.

Assim, nobre é a conclusão do autor quando aduz que:

Eis um dispositivo legal de facílima compreensão gramatical, literal, sendo porém árduo seu exercício prático, haja vista a necessidade de reconhecimento, por quem de direito, da emergência real, havendo por dever distá-la da figura esdrúxula da "emergência criada" ou "fabricada", tudo dentro de sua seara competencial. 
No exame de cada caso, é-se pessoal, respeitado o princípio da impessoalidade; usase a subjetividade, apesar de calcado em situação objetiva; visa-se a atenuar ou até a dirimir os prejuízos a serem causados a pessoas, obras, serviços, equipamentos ou a bens outros quaisquer, sejam eles públicos ou particulares, mas não se pode compactuar com a negligência administrativa e, mais que isso, deve-se combatê-la, denunciá-la, coibi-la.

Conclui-se que:

De toda sorte, é consenso doutrinário que, sob o prisma puramente jurídico descartadas, pois, desse enfoque as incursões políticas periféricas e adjacentes a cada caso concreto -, constituem casos emergenciais, cujo atendimento se faz urgente, sob pena de se causarem danos de reparação duvidosa e com consequências imprevisíveis a pessoas, obras, equipamentos, serviços e outros bens, públicos ou particulares: a necessidade de restabelecimento imediato de fiação elétrica deteriorada que ameaça incendiar um edifício, ou de conduto de água que abastece uma comunidade; a ocorrência de epidemia de cólera, de dengue ou qualquer surto epidêmico; a quebra de máquinas e equipamentos que retarde ou impossibilite a prestação de serviço público; a greve de servidores que exercem atividades consideradas essenciais, na forma da lei, cujo atendimento contínuo é inadiável à população, etc. etc.

Idêntica preocupação à que ora procuramos expor demonstram os estudiosos do Direito Administrativo Lúcia Valle Figueiredo e Sérgio Ferraz, em seu livro Dispensa e Inexigibilidade de Licitação. Ao concordarem com o preciso exame da questão em apreço empreendido por Antonio Carlos Cintra do Amaral, entendem ser condição sine qua non, na análise da emergência, fazer-se límpida e lúcida distinção entre a emergência "real", que provém do inevitável, e aquela resultante da incúria ou inércia administrativa, dando a ambas tratamento similar, no que concerne à necessidade premente de contratação direta, dispensada para tanto licitação, mas sem eximir, no segundo caso, "o responsável pela falha administrativa de sofrer as sanções disciplinares compatíveis.”

Inevitável a comparação do estudo ora mencionado com o proposto, pois percebe-se que mesmo antes da promulgação de uma legislação de amplitude nacional, persistia uma enorme preocupação na forma como os gestores iriam tratar a situação emergencial para fins licitatórios.

Aliás, já naquela época, a doutrina e a jurisprudência começavam a se inclinar sobre a possibilidade de se utilizar o referido instituto da dispensa para atender as emergências fabricadas, já que, acima de tudo, persistia uma situação que exigia da Administração Pública uma ação rápida e eficiente, independentemente da ação ou omissão que lhe deu causa. 
Contudo, uma conclusão se manteve durante todos esses anos, já que embora o consenso da utilização do instituto tenha aumentado, igualmente cresceu a afirmativa de que o causador da emergência "ficta" deve ser punido ante a sua responsabilidade.

\section{A VERIFICAÇÃO DOS REQUISITOS LEGAIS E AS CONSEQUÊNCIAS DE SUA INOBSERVÂNCIA.}

Importante ressaltar que a permissiva acerca da possibilidade de utilização do instituto da dispensa por emergência, independente da causa que a originou, está longe de ser um álibi para o Administrador imprudente, pois esta desídia pode e deve ser apurada pelo competente Processo Administrativo, inclusive com vistas a apuração de ato ímprobo.

Esse é o entendimento mais recente (Acórdão 1.876/2007), onde:

\footnotetext{
A contratação direta com fundamento no inciso IV do art. 24 da Lei n. ${ }^{\circ} 8.666$, de 1993, exige que, concomitantemente, seja apurado se a situação emergencial foi gerada por falta de planejamento, desídia ou má gestão, hipótese que, quem lhe deu causa, será responsabilizado na forma da lei [...].
}

Tal entendimento vem sendo acatado pelos Tribunais de Justiça, como o de Santa Catarina, que no Agravo de Instrumento n. ${ }^{\circ}$ 2014.014919-2 entendeu que persiste ato ímprobo em caso de contratação direta justificada em emergência fabricada.

Para GABARDO (2002, p. 24-30) aponta as dificuldades encontradas em se fixar um sentido para o princípio da eficiência e apresenta as principais aproximações: eficiência como eficácia, efetividade, racionalização, produtividade, economicidade e celeridade. Informa também a existência de especificações da eficiência, em que ao termo eficiência se agrega um adjetivo: eficiência operativa; eficiência técnica; eficiência econômica stricto sensu; eficiência econômica produtiva; eficiência moral.

Desta feita, a contratação direta, fundada no art. 24, IV é possível, independente desta ser decorrer de uma emergência real ou fabricada pela administração, desde que atenda necessidade provisória evitando assim resultado danoso às coisas e pessoas ou que comprometa a segurança das mesmas.

Contudo, sendo constatado que a referida emergência decorreu da ausência de planejamento, da desídia administrativa ou da má utilização dos recursos, deve o administrador, bem como aqueles que deram causa a emergência serem responsabilizados em face da Lei de Responsabilidade Fiscal, bem como perante os Tribunais de Contas. 
Tal conduta, aliás, é repudiada pela lei de improbidade administrativa (Lei n. ${ }^{\circ}$ 8.429/92), que aduz:

Art. $1^{\circ}$. Os atos de improbidade praticados por qualquer agente público, servidor ou não, contra a administração direta, indireta ou fundacional de qualquer dos Poderes da União, dos Estados, do Distrito Federal, dos Municípios, de Território, de empresa incorporada ao patrimônio público ou de entidade para cuja criação ou custeio o erário haja concorrido ou concorra com mais de cinquenta por cento do patrimônio ou da receita anual, serão punidos na forma desta lei.

(...)

Art. 10. Constitui ato de improbidade administrativa que causa lesão ao erário qualquer ação ou omissão, dolosa ou culposa, que enseje perda patrimonial, desvio, apropriação, malbaratamento ou dilapidação dos bens ou haveres das entidades referidas no art. $1^{\circ}$ desta lei, e notadamente:

(...)

VIII - frustrar a licitude de processo licitatório ou dispensá-lo indevidamente;

Neste sentido, frisa-se também a vigência do Decreto Lei n. ${ }^{\circ}$ 201/1967, que estabelece um rol de responsabilidades dos prefeitos, que quando não observados podem culminar na cassação de seus mandatos, além da apuração dos atos na esfera criminal, e para tanto a fiscalização exercida pelo Controle Interno, Ministério Público, Tribunal de Contas e especialmente, pela sociedade podem e devem apontar qualquer ilicitude, seja na utilização do instituto da dispensa, seja no desempenho de qualquer outro ato administrativo dos gestores de nosso país.

\section{CONSIDERAÇÕES FINAIS}

Denota-se que mesmo com uma legislação com mais de 20 anos e utilizada nas três esferas do poder quase que diariamente, ainda não é possível afirmar com exatidão que é a utilização do instituto da dispensa de licitação prevista no inciso IV do artigo 24 da Lei 8.666/93 para abarcar casos de emergência ficta é legal ou correta.

Isto porque a legislação existente não conceitua especificamente o termo emergência, por conseguinte, tal interpretação fica a critério dos juristas, seja através da doutrina, ou perante as inúmeras discussões jurídicas presentes nos Tribunais, quando da análise das ações ou contas daqueles que operam as atividades licitatórias na Administração Pública.

Ao que refletem aos olhos desta pesquisa, percebe-se a suma importância do conhecimento dos setores jurídicos dos órgãos administrativos, que diante da situação prática 
devem orientar seus gestores no sentido de que possível é a utilização deste instituto, o que deve ser feito da forma mais prudente possível, atentando-se aos princípios constitucionais acima de tudo, prevalecendo o interesse público em todos os seus atos, pois cabe interpretação do art. 24, inciso IV, da Lei Geral de Licitações para viabilizar a dispensa de licitação nos casos de emergência decorrente da falta de planejamento administrativo.

Pensar diferente disso seria consentir com a possibilidade da total inércia da Administração Pública ante a necessária contraprestação para com seus jurisdicionados em casos de emergência, ou seja, de possível prejuízo financeiro ou físico as pessoas e exemplos práticos destas situações vem aumentando a cada dia, pois não raros são os casos de gestores inertes e displicentes, que por consequente, chegam as vias da cassação do mandato, deixando uma herança de irregularidades e problemas que não podem ser resolvidos à longo prazo, devendo o sucessor agir com a rapidez e precisão que só a dispensa de licitação - diante dos prazos - pode fornecer.

Ressalta-se, contudo, que a utilização da dispensa de licitação emergencial deve ser fundamentada, atentando sempre aos requisitos legais e formais que a lei sempre impôs, independentemente do fato gerador desta, respeitando o prazo de execução das medidas necessárias a atender a situação de normalidade, devendo estas possuir o escopo de restaurar a situação emergencial relatada nos laudos ou justificativas acostadas no processo administrativo, sendo que a contratação não poderá exceder o prazo máximo de 180 (cento e oitenta) dias, contados da data de constatação da emergência, fato pelo qual não pode a burocracia ensejar a demora no atendimento do serviço público, pois as providências devem ser imediatas.

Contudo, não se pode permitir - embora não haja ferramentas para impedir - que o Poder Judiciário e os Tribunais de Contas criem requisitos para avaliar a possibilidade de aplicação da dispensa de licitação em caso de emergência decorrente de desídia do gestor frente à administração pública, pois se a lei não o fez, jamais poderia o Judiciário "legislar" acerca do tema.

Assim, se a questão for levada aos olhos das cortes judiciais, a análise deve ser feita caso a caso, levando-se em conta a motivação do ato, e não fundamentar-se em critérios estipulados de forma objetiva pelos julgadores.

Por óbvio, embora sejam os Juízes, Ministros e Conselheiros que detém o poder de julgar, ninguém mais capaz de determinar a real necessidade de utilização da dispensa de licitação do que os próprios gestores quando da instauração de uma emergência capaz de fundamentar a utilização do instituto ora estudado. 
Ademais, o que resta lúcido é a necessária apuração das responsabilidades dos gestores públicos quando da má utilização desta ferramenta excepcional, pois a punição dos maus gestores é medida que se faz necessária para coibir que os bons administradores sejam punidos por julgamentos prévios e genéricos acerca da utilização da dispensa como única forma de atender o interesse público de forma eficiente e condizente com o interesse público.

Lembra-se igualmente que o direito não é feito de regras gerais, pois sequer a lei consegue abraçar todos os fatos de uma sociedade. Assim, prudente que os Tribunais flexibilizem a utilização do instituto da dispensa por emergência, evitando que a exceção vire regra, pois a principal solução deste problema é o planejamento administrativo, necessário a qualquer gestor ou gestão.

\section{REFERÊNCIAS}

BANDEIRA DE MELlO, Celso Antonio. Curso de direito administrativo. $28^{a}$ ed. São Paulo: Malheiros, 2010.

BRASIL. Constituição da República Federativa do Brasil de 1988. Brasília-DF. Senado Federal, 05 de outubro de 1988. Disponível em http://www.planalto.gov.br/ccivil_03/Constituicao/Constituicao.htm. Acesso em 15/01/2016.

Lei 8.666 de 21 de junho de 1993. Regulamenta o art. 37, inciso XXI, da Constituição Federal, institui normas para licitações e contratos da Administração Pública e dá outras providências. Diário Oficial da República Federativa do Brasil. Brasília-DF, 22 jun. 1993. Disponível em http://www.planalto.gov.br/ccivil_03/leis/L8666cons.htm. Acesso em $15 / 01 / 2016$.

Lei 8.429 de 02 de junho de 1992. Dispõe sobre as sanções aplicáveis aos agentes públicos nos casos de enriquecimento ilícito no exercício de mandato, cargo, emprego ou função na administração pública direta, indireta ou fundacional e dá outras providências. Diário Oficial da República Federativa do Brasil. Brasília-DF, 03 de jun. 1992. Disponível em http://www.planalto.gov.br/ccivil_03/LEIS/L8429compilado.htm. Acesso em 15/01/2016.

Decreto n. ${ }^{\text {o }} 7257$ de 04 de agosto de 2010. Regulamenta a Medida Provisória n. ${ }^{\circ}$ 494 de 2 de julho de 2010, para dispor sobre o Sistema Nacional de Defesa Civil - SINDEC, sobre o reconhecimento de situação de emergência e estado de calamidade pública, sobre as 
transferências de recursos para ações de socorro, assistência às vítimas, restabelecimento de serviços essenciais e reconstrução nas áreas atingidas por desastre, e dá outras providências. Diário Oficial da República Federativa do Brasil. Brasília-DF, 5 de ago. 2010. Disponível em http://www.planalto.gov.br/ccivil_03/_ato2007-2010/2010/Decreto/D7257.htm. Acesso em $\underline{15 / 01 / 2016}$.

Tribunal de Contas da União. Decisão n. ${ }^{\circ}$ 347/1994. Plenário. Ministro Relator Carlos Átila Álvares da Silva, Sessão 01/06/1994, Dou 21/06/1994. Disponível em http://www.tcu.gov.br/Consultas/Juris/Docs/judoc\%5CDec\%5C19940106\%5CGERADO_TC -8400.pdf. Acesso em 25/08/2015.

- Tribunal de Contas da União. Acórdão n. ${ }^{\circ}$ 1876/2007. Plenário, Processo n. ${ }^{\circ}$ 008.403/1999-6, Relator: Aroldo Sedraz. Publicado no D.O.U. em 14.09.1997. Disponível em https://contas.tcu.gov.br/juris/SvlHighLight. Acesso em 25/08/2015.

. Tribunal de Contas da União. Decisão n. ${ }^{\circ}$ 138/98. Plenário. Processo n. ${ }^{\circ}$ TC 019.365/95-0. Relator: Ademar Paladini Ghis. Publicado no D.O.U. de 07.04.1998. Disponívelemhttp://www.tcu.gov.br/Consultas/Juris/Docs/judoc\%5CDec\%5C20000103\%5C GERADO_TC-1087.pdf. Acessado em 25/08/2015

. Tribunal de Contas da União. Item 9.7.6, TC-014.388/2005-9, Acórdão n. ${ }^{\text {o }}$ 1.920/2011 - $1^{\text {a }}$ Câmara. Publicado no D.O.U. em 05.04.2011; Disponível em www.tcu.gov.br/Consultas/Juris/Docs/judoc/.../AC_7871_32_11_1.doc. Acesso em 25/08/2015;

CARVALHO Leonardo Chaves de. CARVALHO, Luciani Coimbra de. Contratações emergenciais: Análise da visão do Tribunal de Contas da União. Revista da Faculdade de Direito UFPR, Curitiba, v. 59, n. 1, p. 7-34, 2014. Disponível em http://ojs.c3sl.ufpr.br/ojs/index.php/direito/article/view/36363/22431. Acesso em 14/01/2015;

CARVALHO, Paulo de Barros. Direito tributário, linguagem e método. 3 ed. São Paulo: Noeses, 2009.

DINIZ, Maria Helena. Curso de Direito Civil Brasileiro. $7^{\circ}$ volume. 19 ed. São Paulo: Saraiva, 2005. 
DAVILA, Vera Lucia Machado. DI PIETRO, Maria Sylvia Zanella. Temas Polêmicos sobre Licitações e Contratos. 3 ed. São Paulo: Malheiros, 1998.

DI PIETRO, Maria Sylvia Zanella. Direito Administrativo. 27 ed. São Paulo: Atlas, 2014.

FERNANDES, Jorge Ulisses Jacoby. Contratação direta sem licitação. $5^{\mathrm{a}}$ ed. Brasília: Brasília Jurídica, 2004.

FREITAS, Juarez. Responsabilidade civil do Estado e o princípio da proporcionalidade: vedação de excesso e de inoperância In: FREITAS, Juarez (coord.). Responsabilidade civil do Estado. São Paulo: Malheiros, 2006.

FURTADO, Lucas Rocha. Curso de licitações e contratos administrativos. $2^{\mathrm{a}}$ ed. Belo Horizonte: 2009.

GABARDO, Emerson. Princípio constitucional da eficiência administrativa. São Paulo: Dialética, 2002.

GASPARINI, Diógenes. Direito Administrativo. 7. ed. rev. e atual. - São Paulo: Saraiva, 2002.

JUSTEN FILHO, Marçal. Curso de Direito Administrativo. 7 ed. rev., atual e ampl. São Paulo: Fórum, 2011.

JUSTEN FILHO, Marçal. Comentários à lei de Licitações e Contratos Administrativos. $15^{\mathrm{a}}$ ed., Dialética, 2012.

MEIRELLES, Hely Lopes. Direito Administrativo Brasileiro. 27 ed. atual. São Paulo: Malheiros, 2002;

MEIRELLES, Hely Lopes. Direito Administrativo Brasileiro. 40 ed. São Paulo: Malheiros, 2014.

MORAES, Alexandre de. Direito Constitucional. 30 ed. São Paulo: Atlas, 2014.

OLIVEIRA, Jorge Hélio Chaves de. Situações emergenciais e dispensa de licitação: O problema da emergência “criada”. Revista Pensar, Fortaleza, v. 2, n. 2, p.107-111, ago. 1993. 
SANTA CATARINA. Tribunal de Contas do Estado de Santa Catarina. Prejulgado 1395. Oriundo do Processo COM-03/02821287. Decisão 1959/2003. Relator: Conselheiro Wilson

Rogério Wan-Dall. Publicado em 05/08/2003; Disponível em http://www.tce.sc.gov.br/decisoes. Acesso em 25/08/2015.

SILVA, José Afonso da. Curso de direito constitucional positivo. 9. ed. São Paulo: Malheiros, 1992. 